\title{
The Determinants of Home Mortgage Default Probability: The Effect of Loan and Borrower's Characteristics
}

\author{
Y. Rachmansyah ${ }^{1}$, A. Dorkas R.A ${ }^{2}$, Harijono $^{3}$, R. Prabowo ${ }^{4}$ \\ Doctoral Student of Economics and Business Faculty of Satya Wacana Christian University, \\ Central Java, Indonesia ${ }^{1}$, Lecturer at Satya Wacana Christian University, Central Java \\ Indonesia ${ }^{2,3,4}$ \\ \{yanuarrachmansyah1969@gmail.com\}
}

\begin{abstract}
Housing is one of the individuals' basic needs besides food and clothing, and house demand will increase continuously to respond to the increasing population. Consequently, the gaps between housing needs and availability (backlog) in Indonesia remains high. However, home mortgage default probability is still a crucial issue for banks. Investigating the factors that explain home mortgage default probability is important for banks to mitigate the credit default risk. Among these numerous factors, loan and borrowers' characteristics likely play significant roles in determining home mortgage probability. Hence, this study seeks to analyze the effects of credit and borrowers' characteristics on home mortgage default probability. One hundred and thirty-three mortgage customers of the Semarang Branch Office of Bank X are selected as the research sample through the purposive sampling method. Because the dependent variable has discrete values representing different loan qualities (from liquid to doubtful), the data is then analyzed using the ordered probit regression analysis. The results show that loan to value (LTV) is the credit characteristic that affects home mortgage default probability, implying that higher LTV ratios will increase home mortgage default. Meanwhile, education level is the borrower's characteristic that significantly affects home mortgage default probability. This study offers the following managerial implications. First, banks should consider their borrowers' education level. In this respect, education level is closely related to a broader perspective and the amount of income. Second, banks should also consider LTV when allocating home mortgages because it indicates potential borrowers' capacity to pay. Our findings inform banks to take potential borrowers' education levels into account when making home mortgage credit decisions. Education levels are closely related to broader perspectives and higher income. Meanwhile, LTV (a ratio between credit amount and property value) is related to the capacity to repay. Higher property values imply lower LTV ratios and eventually lower default risks. Consequently, banks have to consider borrowers' purchasing power in determining LTV ratios to enhance the probability of home mortgage repayment.
\end{abstract}


Keywords: Default Probability, Loan Characteristics, Borrowers'
Characteristics, Home Mortgage, Credit

\section{Introduction}

Besides food and clothing, housing is the individuals' basic needs. Hence, housing demands will continuously increase in line with the increasing population. However, the gap between housing demands and house availability (backlog) in Indonesia is very high, although the number continues to decline after the government has issued the "one million houses development" policy since 2015. According to the Ministry of Public Works and Public Housing (PUPR-Pekerjaan Umum dan Perumahan Rakyat), the backlog ratio was still 7.6 million units [1] The figure suggests that housing needs are still high in Indonesia. Due to limited purchasing power, most people rely on home mortgage loans in buying houses, as indicated by the annual growth of home mortgage loans of $2.85 \%$. In particular, the proportion of the use of home/ apartment mortgage loans in total residential purchases increases from $71.88 \%$ in quarter IV-2019 to $74.73 \%$ in quarter I-2020 (Figure 1).

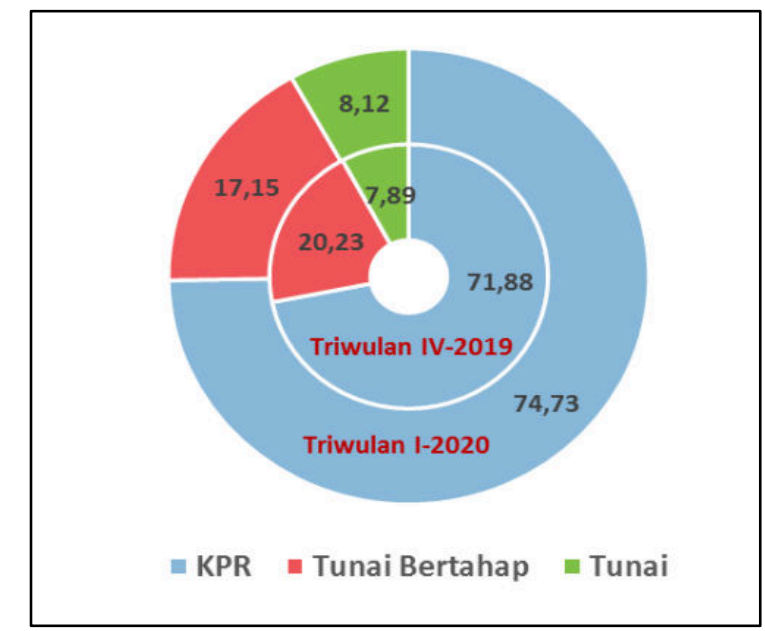

Fig. 1. Consumers' Financing Sources in Purchasing Properties (\% of Consumers' Purchase of Residential Properties)

The above diagram suggests that mortgage loans are still the main financing source of Indonesian people when buying houses. Several factors explain why home/ apartment mortgage loans remain popular amidst high property prices [2], including affordable down payment and monthly instalment; apartment/ home mortgage loans offer numerous flexible features that simplify borrowers in repaying, especially the first-buyers [3]. Prior studies [4] identify borrowers, firms, and credit characteristics that affect credit repayment timeliness. However, prior studies on the determinants of credit defaults that use the Indonesian setting largely focus on general credit and overlook home mortgage loans. In contrast, mortgage loans exhibit different characteristics from other consumptive credits. Thus, this investigation looks to dissect the impact of credit and borrowers' attributes on home loan default probability. It is expected that this study informs banks in making home mortgage loan decisions 


\section{Literature Review}

\subsection{Asymmetry Information}

Asymmetry Information exists when an economic actor has better access to inside information while others cannot have. More specifically [5] defines information asymmetry as a condition when an economic actor possesses better information on negotiated economic objects than other economic actors. Further, [5] divides information asymmetry into two types based on how an economic actor possesses better information than others, that is adverse selection and moral hazard. The adverse selection exists when an economic actor (e.g., a seller) has better information than others (e.g., buyers) before these actors enter an economic contract. Meanwhile, moral hazard refers to a condition when an economic actor exploits her information advantages for her benefits at the expense of other economic actors' after these economic actors enter an economic contract.

Information asymmetry occurs in various transaction processes, such as labor, financial, and insurance markets. In credit markets, there are time gaps between the credit contract is agreed and the repayment periods. According to [6] financial contracts include factors that lead to adverse selection and moral hazard. Meanwhile, as suggested by [7], information imperfection results in at least four credit market problems: adverse selection, moral hazard, lack of insurance, and weak law enforcement. Meanwhile, according to [8] imperfect information affects firms' internal organization and their relationships with labor, capital, and product markets.

\subsection{Risk-taking Behavior}

Risk-taking behavior is an individuals' psychological aspect when making economic decisions. According to [9] behavior is the results of a series of processes that can be divided into several identification processes, namely identifying alternative choices, identifying the consequences of each alternative, evaluating the probability of each consequence, evaluating the potential payoffs of each consequence, and combining all information to make a decision. Meanwhile, [10] define risks as uncertainty that may imply negative or positive consequences. According to [11], risk-taking behavior refers to how individuals behave in risky situations that involve a high degree of uncertainty and likely imply losses. According to [12], risktaking behavior refers to activities that potentially involve novel or risky matters that invite anxiety to most human beings.

\subsection{Hypothesis Development}

In this study, credit characteristics include loan to value (LTV), interest rate, and loan amount. [13] find that credit characteristics strongly affect home mortgage default probability. Specifically, the LTV is the ratio between the bank's maximum loan amount and the estimated value of the property at the time of credit agreement is made [14]. LTV is a prudential macro instrument to anticipate increased mortgage demands because higher mortgage growth potentially exposes banks to various risks. Higher LTV ratios imply lower amounts of down payment. Consequently, the amounts of mortgage loans are higher, and borrowers' repayment burden will be higher. In this respect, higher borrowers' repayment burden will increase home mortgage default probability. 
Previous research related to LTV was done by [15] demonstrates that LTV affects default probability. The finding is supported by [16] and [17] who show that the LTV ratio is a strong predictor of home mortgage default probability. Both variables are also positively associated. Other studies on LTV by [13][18][19][20] indicate that borrowers are more likely to exhibit loan default when they have higher LTV ratios. Thus, we propose the following first hypothesis: H1: LTV positively affects home mortgage default probability.

Interest rate is the returns of loans that are usually stated in the percentage of loans given [21]. Meanwhile, according to [22], credit interest is the price that borrowers have to pay to banks. Banks should be able to determine the interest rate charged to their potential borrowers. On the one hand, charging interest rates too high will likely discourage potential borrowers from applying credits to the bank, and other banks will outcompete the bank. On the other hand, lower interest rates will erode banks' profits. Changes in credit interest rates are a factor that affects systematic risks. In this respect, higher home mortgage interest rates will increase default risk. Meanwhile, lower home mortgage interest rates will attract potential borrowers, and mortgage-backed residential properties' demands will increase. Further, borrowers will have to make lower amounts of credit repayment to reduce home mortgage default probability. [23] demonstrate the significantly positive impact of credit interest rate on non- performing loans (NPL). Similarly, [24] [25] conclude that interest rates affect default probability. Hence, the following is our second hypothesis: H2: Interest rate positively affects home mortgage default probability.

Credit amount refers to the amounts of credit given to customers according to the credit types and borrowers' needs. [26] show that credit amount affects NPL. Credit amount is affected by credit demands by borrowers. This argument is supported by banks' role as agents of development that makes banks the main financing alternative for potential borrowers. Prior studies of [4] [19][24][27][28] indicate that credit amount affects default probability. Based on these arguments, the third hypothesis is: H3: Credit amounts positively affect home mortgage default probability.

Besides the financial variables, personal characteristics such as education, income, and gender are similarly important to explain credit default [29]. In general, younger individuals enter the job market more currently and earn less than older ones who are more experienced and have a more stable income. Consequently, age will affect individuals' ability to repay their loans, including home mortgage loans. Those who enter the job market more recently and aim to have residential houses rely on home mortgage as the financing scheme. Further, younger individuals tend to have less experience in managing their personal finances, including repaying their home mortgages. [30][31][32] conclude that age negatively affects credit default probability. Hence, the following is our fourth hypothesis: H4: Age negatively affects home mortgage default probability.

Education refers to borrowers' formal education level that is measured by order measures. Highly educated individuals arguably have better skills and knowledge in managing their jobs and income. More specifically, education is: (1) the process of developing ones' ability, attitude, and behaviors in their society; and (2) a social process in which individuals are exposed to controlled and selected environments (especially from their schools) that enable them to acquire or experience optimal developed social abilities. [30][31][32][33] conclude that education level affects household debt default. Based on these arguments, we propose the following fifth hypothesis: H5:Education level negatively affects home mortgage default probability.

Income refers to revenues stated in monetary units received by individuals or households based on their earnings or other revenue sources. Individuals earn incomes from various 
sources and occupations, such as civil servants, entrepreneurs, farmers, and artists. Revenues or income affects default probability [4][19][28]. In line with these results, [34] finds that annual net income is a factor that affects loan repayment. Similarly, [35] finds that income is a factor that affects loan repayment. Meanwhile, [36] document that income and business types affect microcredit repayment. Entrepreneurs with higher income repay their loans moretimely. Further, [37] observes that unexpected expenditures are the main reason of credit repayment failure. Besides, borrowers with lower income tend to experience default. In general, those with higher household income are less likely to experience credit default [38]. Hence, the following is our sixth hypothesis: H6: Income negatively affects home mortgage default probability.

\section{Methodology}

According to [39] population refers to the generalization area that consists of objects or subjects with certain quality or characteristics set by the researchers to investigate and conclude. The population of this study is all borrowers of Bank X in 2018-2019 who reside in Semarang City. Further, as suggested by [39] sample is the part of the amount and characteristics of the population. We select the sample using the non-probability sampling (purposive sampling) based on the following criteria: (1) home mortgage borrower of bank X, (2) having been a borrower for at least two years, (3) residing in Semarang City, and (4) a Muslim. Based on these criteria, we manage to generate 133 borrowers of Bank X as the sample. The following table explains the research variables, the operational definition of the research variables, the operational indicators for each variable, and the measurement scale.

Table 1. Research Variables, Operational Definitions, and Indicators

\begin{tabular}{|c|c|c|c|}
\hline Variable & Operational Definition & Indicator & Scale \\
\hline Home & Borrowers' inability to repay & $1=$ pass $/$ liquid & Ordinal \\
\hline Mortgage & loans $[40]$ & $2=$ special mention & \\
\hline Default & & $3=$ substandard & \\
\hline Probability & & $\begin{array}{l}4=\text { doubtful } \\
5=\text { loss }\end{array}$ & \\
\hline $\begin{array}{l}\text { Credit Interest } \\
\text { Rate }\end{array}$ & $\begin{array}{l}\text { Prices that should be paid by } \\
\text { borrowers to banks [22] }\end{array}$ & $\begin{array}{l}\text { Credit interest rate of } \\
\text { Bank } X \text { that is measured } \\
\text { in percentage }\end{array}$ & Ratio \\
\hline Credit Amount & $\begin{array}{l}\text { Credit amount given to } \\
\text { borrowers according to credit } \\
\text { types and needs. }\end{array}$ & $\begin{array}{l}\text { Credit amount in Bank X, } \\
\text { measured in Rupiah }\end{array}$ & Ratio \\
\hline Loan to Value & $\begin{array}{l}\text { The ratio between credit } \\
\text { amount can be given by the } \\
\text { bank and property's current } \\
\text { value as the collateral [14]. }\end{array}$ & $\begin{array}{c}\text { Loan amount } \\
\text { LTV }=\text {--:-------- } \\
\text { Property value }\end{array}$ & Ratio \\
\hline Age & Borrowers' age. & $\begin{array}{l}\text { Age }=\text { research year - } \\
\text { borrowers' year of birth }\end{array}$ & Ratio \\
\hline $\begin{array}{l}\text { Education } \\
\text { Level }\end{array}$ & $\begin{array}{l}\text { Borrowers' formal education } \\
\text { level. }\end{array}$ & $\begin{array}{l}\text { 1. Senior High School } \\
\text { 2. Diploma degree } \\
\text { 3. Bachelor degree } \\
\text { 4. Master degree } \\
\text { 5. Ph.D. degree }\end{array}$ & Ordinal \\
\hline Income & $\begin{array}{l}\text { The sum of all the respondent's } \\
\text { revenues in the forms of }\end{array}$ & $\begin{array}{l}\text { Income }=\text { salary }+ \text { wage }+ \\
\text { allowance } \quad+\quad \text { other }\end{array}$ & Ratio \\
\hline
\end{tabular}




\begin{tabular}{lllc}
\hline Variable & $\begin{array}{l}\text { Operational Definition } \\
\text { salaries, wages, or other } \\
\text { revenues within a month. }\end{array}$ & $\begin{array}{l}\text { Indicator } \\
\text { revenues }\end{array}$ & Scale \\
\hline
\end{tabular}

This study uses order probit regression to analyze the data as the development of probit analysis. Probit model analyzes the relationship between the qualitative response variable and the qualitative predictor variables, or the combination of both. This model relies on the Normal Cumulative Distribution Function (CDF) to explain the equation function [41]. Thus, home mortgage default probability depends on the unobserved utility index.

$\mathrm{Y}_{\mathrm{i}}=\beta_{1}+\beta_{2} \mathrm{X}_{1}$

Order probit model develops the probit model to predict the probability of an event with the ordinal dependent variable with the following equation:

$Y_{i}=\beta o+\sum_{i=1}^{i=6} \beta i X i+\mu i t$

Where:

$\mathrm{Y}_{\mathrm{i}}=0$ if $y_{i}^{*} \leq \mu_{0}$

$\mathrm{Y}_{\mathrm{i}}=1$ if $\mu_{0}<y_{i}^{*} \leq \mu_{1}$

$\mathrm{Y}_{\mathrm{i}}=2$ if $\mu_{1}<y_{i}^{*} \leq \mu_{2}$

$\mathrm{Y}_{\mathrm{i}}=\mathrm{j}$ if $y_{i}^{*} \geq \mu_{j-1}$

With:

$y_{i}^{*}=$ dependent variable

$\mathrm{Y}_{\mathrm{i}}=$ respondents' preference levels in ordinal ranks $(0-\mathrm{j})$

$\mathrm{X}=$ independent variable

$\varepsilon i=$ random utility

$\beta=$ variable coefficient

$\mu=$ values that limit the dependent variable $y_{i}^{*}$

Next, the following is our order probit empirical model:

$Y=\beta_{0}+\beta_{1} X_{1}+\beta_{2} X_{2}+\beta_{3} X_{3}+\beta_{4} X_{4}+\beta_{5} X_{5}+\beta_{6} X_{6}$

Where:

$\mathrm{Y}$ : home mortgage default probability

$\mathrm{X}_{1}$ : interest rate

$\mathrm{X}_{2}$ : loan to value

$\mathrm{X}_{3}$ : the logarithmic value of credit amount

$\mathrm{X}_{4}$ : the logarithmic value of borrowers' income

$\mathrm{X}_{5}$ : borrowers' age at the time of credit application

$\mathrm{X}_{6}$ : borrowers' education level

$\beta_{0}$ : intercept/constant

$\beta_{1-6}$ : regression coefficient

$\varepsilon \quad$ : error term 


\section{Result and Discussion}

\subsection{Respondents' Profiles}

Our sample is home mortgage borrowers of Bank X who reside in Semarang City, the capital city of Central Java Province, that experiences a very high property growth. This city also has a diverse population with vibrant religious and sociocultural dynamics. This study uses secondary data from 133 borrowers' approved home mortgage applications up to 2019 . Table 2 below demonstrates the respondents' characteristics.

Table 2. Respondents' Characteristics

\begin{tabular}{|c|c|c|}
\hline Characteristics & Frequency & Percentage \\
\hline \multicolumn{3}{|l|}{ Sex } \\
\hline - male & 85 & 63.91 \\
\hline - female & 48 & 36.09 \\
\hline \multicolumn{3}{|l|}{ Age } \\
\hline$<=30$ years & 36 & 27.07 \\
\hline $31-40$ years & 49 & 36.84 \\
\hline $41-50$ years & 35 & 26.32 \\
\hline$>50$ years & 13 & 9.77 \\
\hline \multicolumn{3}{|l|}{ Education } \\
\hline - Senior High School & 25 & 18.8 \\
\hline - Diploma & 16 & 12.03 \\
\hline - Bachelor (S1) & 65 & 48.87 \\
\hline - Master (S2) & 26 & 19.55 \\
\hline - Doctor (S3) & 1 & 0.75 \\
\hline \multicolumn{3}{|l|}{ Occupation } \\
\hline - Civil servant & 47 & 35,34 \\
\hline - Private employee & 59 & 44,36 \\
\hline - Military/ Police & 7 & 5.26 \\
\hline - Local/ national SOE & 7 & 5.26 \\
\hline - Banker & 4 & 3.01 \\
\hline - Lecturer & 4 & 3.01 \\
\hline - Doctor & 2 & 1.5 \\
\hline - Notary & 2 & 1.5 \\
\hline - Contractor & 1 & 0.75 \\
\hline \multicolumn{3}{|l|}{ Income } \\
\hline$<=5$ million & 7 & 5.26 \\
\hline$>5-10$ million & 51 & 38.35 \\
\hline$>10-15$ million & 35 & 26.32 \\
\hline$>15$ million & 40 & 30.08 \\
\hline
\end{tabular}

The above table informs that most respondents are male $(85$ or $63.91 \%$ of total respondents), indicating that men mainly make home mortgage loan decisions likely because of their role as the family head who make financial decisions. Next, most respondents are between 31-40 years old (49 respondents or $36.84 \%$ ), implying that the home mortgage borrowers of Bank X are mostly in their productive ages and therefore have better abilities to repay their loans. The table above also informs that most respondents have a bachelor's degree (65 respondents or $48.87 \%$ of total respondents), indicating that respondents have sufficient 
knowledge of their responsibilities to repay loans. Next, most respondents work in the private sector (59 respondents or $44.36 \%$ of total respondents) and public sector as civil servants (47 respondents or $35.34 \%$ of total respondents), suggesting that home mortgage borrowers of Bank $\mathrm{X}$ in Semarang City earn a stable income and are therefore eligible to obtain home mortgage credit financing. Lastly, most respondents earn income between $5-10$ million rupiahs (51 respondents or $38.35 \%$ of total respondents). The figures imply that home mortgage borrowers of Bank $\mathrm{X}$ in Semarang earn sufficiently to fulfil their obligations in repaying their home mortgage loans timely.

\subsection{Main Analysis}

This study used order probit model to investigate the determinant of home mortgage default probability in Semarang City. The results of the probit analysis can be seen in the table as follows.

Table 3. Summaries of Order Probit Analysis Results

\begin{tabular}{llccc}
\hline $\begin{array}{c}\text { Independent } \\
\text { Variable }\end{array}$ & Coefficient & $\begin{array}{c}\text { Robust } \\
\text { Std. Err }\end{array}$ & $\mathbf{Z}$ & $\mathbf{P}>|\mathbf{z}|$ \\
\hline Interest Rate & $-0.8569 \#$ & 0.70949 & 1.21 & 0.227 \\
Loan to Value & 0.0228 & 0.01195 & 1.91 & $0.056 *$ \\
Credit Amount & 0.0207 & 0.29407 & 0.07 & 0.944 \\
Income & -0.3188 & 0.30776 & -1.04 & 0.300 \\
Age & $0.0110 \#$ & 0.01234 & 0.90 & 0.369 \\
Education & -0.3294 & 0.11387 & -2.89 & $0.004 * *$ \\
& & & & $*$ \\
\hline Dependent Var. & $:$ Default Probability & & \\
Wald & $: 27.88$ & & Explanation: & \\
Log-likelihood & $:-62.1560$ & $* * *$ significant up to $1 \%$ \\
Prob. Sig. & $: 0.0002 * * *$ & $* *$ significant up to $5 \%$ \\
Pseudo R ${ }^{2}$ & $: 0.166$ & *significant up to $10 \%$ \\
$\mathrm{~N}$ & $: 133$ & & \\
\hline
\end{tabular}

Source: Secondary data (processed), 2020)

Table 3 above suggests that two variables significantly affect the dependent variable, namely LTV and education. The Wald value of 27.88 (significant at 0.0002 ) indicates that our order probit model fits with the data and can be used for hypothesis testing

\subsection{Discussion}

\section{a) The Impacts of Credit Characteristics on Home Mortgage Default Probability}

Credit characteristics include LTV ratio, interest rate, and credit amount. [13] find that credit characteristics strongly explain home mortgage default probability. Our results show that LTV is positively associated with higher home mortgage default probability. The findings support our hypothesis that predicts that LTV positively affects home mortgage default probability. Further, our results are in line with [15][20] who conclude that LTV positively affects credit default probability. The findings also support [16][17][42] who show that LTV is positively associated with home mortgage default probability. Ours is also in line with other studies of [18][19] who conclude that default risk is higher when the LTV ratio is also greater. However, our results differ from [43][44] who observe that the LTV ratio does 
not affect credit default probability.

The results indicate that interest rate does not affect home mortgage default probability. [15][45] who document that interest rate does not affect credit risk. However, our findings are different from [46] who conclude that higher credit risks imply higher interest rates demanded by banks to compensate for the risk. The results also differ from [23][24][25] who conclude that interest rate affects credit risk. This study demonstrates that credit amount does not affect home mortgage default probability of bank X's borrowers. The results suggest that bank X has adjusted credits granted to their borrowers with borrowers' repayment ability, leading to lower default probability. Besides, bank X has adjusted credit amount with repayment periods and borrowers' income. The findings are in line with [47] who documents that credit amount negatively affects loss credit. However, ours are different from [4][19][24][27] who show that credit amount affects default probability.

Overall, the results support the asymmetric information theory. This theory argues that lenders (banks) have inside information that borrowers cannot access in the mortgage loan contracts. The asymmetry will lead to higher credit risk or credit default probability. In this respect, potential borrowers do not have complete information on credit characteristics, while banks have complete information of credit characteristics. Consequently, information asymmetry exists, and credit default probability increases.

\section{b) The Impacts of Borrowers' Characteristics on Home Mortgage Default Probability}

The results demonstrate that income does not significantly affect home mortgage default probability. Hence, banks have identified borrowers' income that borrowers have sufficient income and can fulfil their obligations to repay their home mortgage loans. Banks have to consider potential borrowers' income to allocate mortgage credits prudently. The results are different from [33] who study the determinants of household debt defaults in Chile. Their results conclude that sex, marital status, age, family income, and education level affect household debt default. Similarly, ours is different from [30][31][32] who observe that demographic factors (age, sex, education level, number of family members, and income) affect household debt default.

Younger individuals tend to be less experienced and earn less than older ones. Our findings indicate that age does not statistically affect home mortgage default probability. Hence, home mortgage default probability of Bank X is not affected by borrowers' age. However, the findings do not support [30] [31][32][33] who conclude that age affects home mortgage default. Our results demonstrate that education level negatively affects home mortgage default probability. Thus, borrowers with higher education levels are less likely to have home mortgage defaults. Consequently, banks should consider the education levels of their borrowers. Our findings are in line with [30][31][32][33] who demonstrate that education levels affect household debt default.

Overall, the findings support the asymmetric information theory. This theory applies in credit transactions such as home mortgages that will result in credit risk or default. Specifically, borrowers and banks do not have equal information. Borrowers have private information on their behavior and characteristics before the credit contracts are set. Meanwhile, banks as the creditors do not have complete information on borrowers' characteristics. Consequently, credit transactions are subject to default risk. As suggested by [48] banks inherently incur information asymmetry problems that make it difficult for banks to monitor their borrowers. Banks that can reduce information asymmetry will have better credit decisions and less costly monitoring mechanisms. 


\section{Conclusions}

LTV ratio is the credit characteristic that significantly affects home mortgage default probability. Hence, higher LTV ratios will increase home mortgage default probability. Meanwhile, interest rate and credit amount do not statistically affect home mortgage default probability in Bank X. The results suggest that borrowers do not take interest rates into account when applying for home mortgage loans. Instead, they are motivated by the desire to fulfil their housing and residential needs. Similarly, credit amount does not affect home mortgage default probability because borrowers usually apply for home mortgage loans according to their upper limits and abilities to repay their loans. In this study, education level is the borrowers' characteristic that significantly affects home mortgage default probability in Bank X (negative effect). Thus, more highly educated borrowers are less likely to experience home mortgage defaults. Besides, highly educated individuals have the capacities to earn a higher income and manage their income better. Consequently, it is easier for them to repay their home mortgage loans than less educated ones.

Overall, our findings inform banks to take potential borrowers' education levels into account when making home mortgage credit decisions. Education levels are closely related to broader perspectives and higher income. More educated individuals will likely have better jobs and earn higher income that enable borrowers to repay their home mortgage loans. Meanwhile, LTV (a ratio between credit amount and property value) is related to the capacity to repay. Higher property values imply lower LTV ratios and eventually lower default risks. Consequently, banks have to consider borrowers' purchasing power in determining LTV ratios to enhance the probability of home mortgage repayment.

\section{References}

[1] E. Hutapea, "Per 8 Maret 2019, 'Backlog' Rumah 7,6 Juta Unit," Kompas.com, 2019. https://properti.kompas.com/ read/2019/03/11/104252821/per-8-maret-2019-backlogrumah-76-juta-unit?page=all. (accessed Apr. 12, 2020).

[2] BI Survey, "Survei Harga Properti Residensial Tri Wulan I-2020," Bank Indonesia, Jakarta NV - Tri Wulan I-2020, 2020. [Online]. Available: https://www.bi.go.id/id/ publikasi/survei/harga-properti-primer/Pages/SHPR-Tw.I-2020.aspx.

[3] A. K. Pakpahan, "COVID-19 dan Implikasi Bagi Usaha Mikro, Kecil, dan Menengah," JIHI J. Ilm. Hub. Int., vol. Edisi Khus, no. April, 2020, pp. 59-64, 2020, [Online]. Available:

http://journal.unpar.ac.id/index.php/JurnalIlmiahHubungan Internasiona/article/view/3870.

[4] A. . Roslan and M. Z. Karim, "Determinants of Microcredit Repayment in Malaysia: The Case of Agrobank," Humanit. Sci. J., vol. 4, no. 1, pp. 45-52, 2009.

[5] W. R. Scott, Financial Accounting Theory, Fifth Edit. Canada: Prentice Hall, 2009.

[6] J. Stiglitz, "Markets, Market Failures, and Development," Am. Econ. Rev., vol. 79, no. 2, pp. 197-203, 1989, [Online]. Available: https://econpapers.repec.org/RePEc:aea:aecrev: v:79:y:1989:i:2:p:197-203.

[7] F. Simtowe and M. Zeller, "Determinants of moral hazard in microfinance: Empirical evidence from joint liability lending programs in Malawi," Savings Dev., vol. 30, no. SUPPL., pp. 5-38, 2006, doi: 10.2307/23026339.

[8] B. C. Greenwald, M. Kohn, and J. E. Stiglitz, "Financial market imperfections and 
productivity growth," J. Econ. Behav. Organ., vol. 13, no. 3, pp. 321-345, 1990, doi: 10.1016/0167-2681(90)90004-W.

[9] L. Steinberg, Adolescence, 11th ed. New York: Mc Graw Hill Inc, 2017.

[10] D. Hillson and W. R. Murray, Understanding and Managing Risk Attitude. Aldershot, United Kingdom: Gower Publishing Ltd, 2005.

[11] F. J. Yates, Risk Taking Behavior. New York: John Willey and Sons, Inc, 1994.

[12] M. R. Levenson, "Risk Taking and Personality," J. Pers. Soc. Psychol., vol. 58, no. 6, pp. 1073-1080, 1990, doi: 10.1037/0022-3514.58.6.1073.

[13] R. G. Quercia and M. A. Stegman, "Residential Mortgage Default: A Review of the Literature," J. Hous. Res., vol. 3, no. 2, pp. 341-379, 1992, [Online]. Available: http://www.jstor.org/stable/24841960\%0Ahttp://about.jstor.org/terms.

[14] PBI, "Peraturan Bank Indonesia (PBI) No. 21/13/PBI/2019 tentang Perubahan Atas Peraturan Bank Indonesia Nomor 20/8/PBI/2018 Tentang Rasio Loan To Value Untuk Kredit Properti, Rasio Financing To Value Untuk Pembiayaan Properti, dan Uang Muka Untuk Kredit.” Bank Indonesia, Jakarta, 2019.

[15] J. B. Kau, D. C. Keenan, C. Lyubimov, and V. C. Slawson, "Asymmetric Information in the Subprime Mortgage Market," J. Real Estate Financ. Econ., vol. 44, no. 1-2, pp. 67-89, 2012, doi: 10.1007/s11146-010-9288-6.

[16] T. S. Campbell and J. K. Dietrich, "The Determinants of Default on Insured Conventional Residential Mortgage Loans,” J. Finance, vol. 38, no. 5, pp. 1569-1581, 2017.

[17] Y. Deng, J. M. Quigley, R. Van Order, and F. Mac, "Mortgage default and low downpayment loans: The costs of public subsidy," Reg. Sci. Urban Econ., vol. 26, no. 3-4, pp. 263-285, 1996, doi: 10.1016/0166-0462(95)02116-7.

[18] W. R. Archer and B. C. Smith, "Residential Mortgage Default: The Roles of House Price Volatility, Euphoria and the Borrower's Put Option. , 2013, 46:2, 355-78.," J. Real Estate Econ. Financ., vol. 46, no. 2, pp. 355-378, 2013.

[19] R. G. Quercia, A. Pennington-Cross, and C. Yue Tian, "Mortgage Default and Prepayment Risks among Moderate- and Low-Income Households," Real Estate Econ. Econ., vol. 40, no. Number Supplement 1 pS159-S198,40p), 2012.

[20] A. C. Ghent and M. Kudlyak, "Recourse and residential mortgage default: Evidence from US states," Rev. Financ. Stud., vol. 24, no. 9, pp. 3139-3186, 2011, doi: 10.1093/rfs/hhr055.

[21] C. A. Pohan, Manajemen Perpajakan. Jakarta: PT. Gramedia Pustaka Utama, 2013.

[22] Kasmir, Bank dan Lembaga Kuangan Lainnya. Jakarta: PT. Raja Grafindo Persada, 2012.

[23] B. M. Misra and S. Dhal., "Pro-cyclical management of non-performing loans by the Indian public sector banks," BIS Asian Res. Pap., vol. JUni, 2010.

[24] L. Hock-Eam and S. G. Yeok, "Estimating The Determinants Of Vehicle Loan Default In Malaysia: An Exploratory Study," Int. J. Manag. Stud., vol. 24, no. 1, pp. 73-90, 2017.

[25] D. A. O. Pertiwi and E. D. Arifianto, "Loss Given Default (LGD) Kredit Pemilikan Rumah (KPR) di Indonesia: Analisis Model Industri Perbankan Dan Bank Btn Cabang Purwokerto Tahun 2002-2013," Diponegoro J. Manag., vol. 3, no. 3, pp. 1-15, 2014.

[26] A. Carolina and M. Madyan, "Dampak bank specific variables pada rasio non performing loan dalam sistem perbankan indonesia," J. Manaj. Teor. dan Terap., vol. 8, no. 3, pp. 140-153, 2015.

[27] R. Hu, M. Liu, P. He, and Y. Ma, "Can Investors on P2P Lending Platforms Identify 
Default Risk?," Int. J. Electron. Commer., vol. 23, no. 1, pp. 63-84, 2019, doi: 10.1080/10864415.2018.1512279.

[28] M. R. Kohansal and H. Mansoori, "Factors Affecting on Loan Repayment Performanceof Farmers in Khorasan -Razavi Province of Iran",", in Conference on International Research on Food Security, Natural Resource Management and Rural Development, 2009.

[29] E. C. Lawrence and N. Arshadi, "A Multinomial Logit Analysis of Problem Loan Resolution Choices in Banking," J. Money, Credit Bank., vol. 27, no. 1, p. 202, 1995, doi: $10.2307 / 2077859$.

[30] R. Avery, P. Calem, and G. Canner, "Consumer credit scoring: do situational circumstances matter?," J. Bank. Financ., vol. 28, no. 4, pp. 835-856, 2004.

[31] M. Sharma and M. Zeller, "Repayment performance in group-based credit programs in Bangladesh: An empirical analysis.," World Dev., vol. 25, no. 10, pp. 1731-1742, 1997.

[32] J. Stavin, "Credit Card Borrowing, Delinquency, and Personal Bankruptcy," New Engl. Econ. Rev., no. July, pp. 15-30, 2000.

[33] R. Alfaro and N. Gallardo, "The determinants of household debt default," Rev. Anal. Econ., vol. 27, no. 1, pp. 55-70, 2012.

[34] J. . Oladeebo and O. . Oladeebo, "Determinants of Loan Repaymen Among smallholder Farmers in Ogbomoso Agricultural Zone of Oyo State, Nigeria.," J. Soc. Sci., vol. 17, no. 1, pp. 59-62, 2008.

[35] Y. Sanrego and M. Antonio, "The Effect of Social Capital on Loan Repayment (A Study on Group Lending Model (GLM) Application In Islamic Microfinance Institution)," J. Ekon. Bisnis Indones. (Fakultas Ekon. dan Bisnis Univ. Gadjah Mada), vol. 28, no. 2, pp. 188-210, 2015, doi: 10.22146/jieb.6222.

[36] N. Bhatt and S.-Y. Tang, "Determinants of Repayment in Microcredit: Evidence from Programs in The United States.," Int. J. Urban Reg. Res., vol. 26, no. 2, 2002.

[37] M. Vijayakumar, "A Study on the Factors Affecting the Consumers to Default the Housing Loan,” Sumedha J. Manag., vol. 5, no. 4, pp. 82-91, 2017.

[38] L. G. Knapp and T. G. Seaks, "An Analysis of the Probability of Default on Federally Guranteed Student Loans," Rev. Econ. Stat., vol. 74, no. 3, p. 404, 1992, doi: $10.2307 / 2109484$.

[39] Sugiyono, Metode Penelitian Kuantitatif, Kualitatif dan R\&D. Bandung: PT. ALfabeta, 2016.

[40] J. Colquitt, Credit Risk Management: How to Avoid Len-ding Disasters and Maximize Earnings. Two Penn Plaza, New York: McGraw-Hill, 2007.

[41] D. N. Gujarati and D. C. Porter, Basic Econometrics, 5th ed. New York: McGrawHill/Irwin, 2009.

[42] E. C. Lawrence, L. D. Smith, and M. Rhoades, "An analysis of default risk in mobile home credit," J. Bank. Financ., vol. 16, no. 2, pp. 299-312, 1992, [Online]. Available: https://econpapers.repec.org/RePEc:eee:jbfina:v:16:y:1992:i:2:p:299-312.

[43] B. W. Ambrose and C. A. Capone, "Modeling the Conditional Probability of Foreclosure in the Context of Single-Family Mortgage Default Resolutions.," Real Estate Econ., vol. 26, no. 3, pp. 391-429, 1998.

[44] A. Kelly, "Skin in the Game: Zero Downpayment Mortgage Default," ournal Hous. Res., vol. 17, no. 2, pp. 75-99, 2008.

[45] O. E. Ergungor and S. Moulton, "Beyond the transaction: Banks and mortgage default of low-income homebuyers," J. Money, Credit Bank., vol. 46, no. 8, pp. 1721-1752, 
2014, doi: $10.1111 / \mathrm{jmcb} .12164$.

[46] R. Beck, P. Jakubik, and A. Piloiu, "Non-performing loans: what matters in addition to the economic cycle?," 2013.

[47] D. Dwihandayani, "Analisis Kinerja Non Performing Loan (NPL) Perbankan Di Indonesia Dan Faktor-Faktor Yang Mempengaruhi NPL,” J. Ilm. Ekon. Bisnis, vol. 22, no. 3, p. 228985, 2017.

[48] G. Caprio, L. Laeven, and R. Levine, "Governance and bank valuation," J. Financ. Intermediation, vol. 16, no. 4, pp. 584-617, 2007, doi: 10.1016/j.jfi.2006.10.003. 